PHARMACONJurnal Ilmiah Farmasi - UNSRAT Vol. 9 No. 1 FEBRUARI 2020 ISSN 2302 - 2493

\title{
FORMULASI DAN UJI AKTIVITAS SABUN CAIR EKSTRAK ETANOL HERBA SELEDRI (Apium graveolens L) TERHADAP BAKTERI Staphylococcus aureus
}

\author{
Hamido Persada Hutauruk ${ }^{1)}$, Paulina V. Y. Yamlean ${ }^{1)}$, Weny Wiyono ${ }^{1)}$ \\ ${ }^{1)}$ Program Studi Farmasi FMIPA UNSRAT Manado, 95115
}

\begin{abstract}
Celery plants (Apium graveolens L.) contain flavonoids, saponins, $1 \%$ tannins, $0.033 \%$ essential oils, apiin, apigenin, choline, lipase, asparagine. which can inhibit bacterial activity. This study aims to formulate, and test the antibacterial activity of liquid celery herbal soap (Apium graveolens L) liquid soap preparations at concentrations of $1 \%, 2 \%, 4 \%$ and $8 \%$. This study uses an experimental method by testing the parameters of the physical evaluation requirements of liquid soap preparations. Physical evaluation of the preparation includes organoleptic test, $\mathrm{pH}$ test, high test and foam stability, water content test, free alkali test, specific gravity test and irritation test. The results of the study on the quality test or physical evaluation of celery herbal liquid soap liquid with a concentration of 1\%, 2\%, 4\% and $8 \%$ meet the requirements set by SNI. Antibacterial testing of celery herbal liquid soap preparations against Staphylococcus aureus bacteria observed on UVVis spectrophotometer produced a minimum inhibitory level of 1.267 for a concentration of 1\%, 0.45 for a concentration of $2 \%,-0.037$ for a concentration of 4\%, and -0.124 for a concentration of $8 \%$. It can be concluded that liquid soap concentrations of 1\%, 2\%, 4\% and $8 \%$ of celery herbal extract can be formulated as liquid soap preparations and have antibacterial activity at concentrations of $1 \%, 2 \%, 4 \%$, and $8 \%$.
\end{abstract}

Keywords: Celery (Apium graveolens L), Liquid soap, Staphylococcus aureus, Antibacterial

\begin{abstract}
ABSTRAK
Tanaman Seledri (Apium graveolens L.) mengandung flavonoid, saponin, tannin 1\%, minyak atsiri $0,033 \%$, apiin, apigenin, kolin, lipase, asparagine. yang mampu menghambat aktivitas bakteri. Penelitian ini bertujuan untuk memformulasi, serta menguji aktivitas antibakteri sediaan sabun cair ekstrak etanol herba Seledri (Apium graveolens L) pada kosentrasi 1\%, 2\%, 4\% dan 8\%. Penelitian ini menggunakan metode ekperimental dengan melakukan pengujian parameter persyaratan evaluasi fisik sediaan sabun cair. Evaluasi fisik sediaan meliputi uji organoleptik, uji pH, uji tinggi dan kestabilan busa, uji kadar air, uji alkali bebas, uji bobot jenis dan uji iritasi. Hasil penelitian pada uji kualitas atau evaluasi fisik dari sabun cair Ekstrak Etanol Herba Seledri dengan konsentrasi $1 \%, 2 \%, 4 \%$ dan $8 \%$ memenuhi syarat yang telah ditetapkan oleh SNI. Pengujian antibakteri sediaan sabun cair Ekstrak Etanol Herba Seledri pada bakteri staphylococcus aureus yang diamati pada spektrofotometer UV-Vis menghasilkan kadar hambat minimum 1,267 untuk konsentrasi $1 \%$, 0,45 untuk konsentrasi 2\%, -0,037 untuk konsentrasi 4\%, dan -0,124 untuk konsentrasi 8\%. Dapat disimpulkan bahwa sabun cair kosentrasi 1\%, 2\%, 4\% dan 8\% Ekstrak Etanol Herba Seledri dapat diformulasi sebagai sediaan sabun cair yang stabil dan memiliki aktivitas antibakteri pada konsentrasi $1 \%, 2 \%, 4 \%$, dan $8 \%$.
\end{abstract}

Kata kunci : Seledri (Apium graveolens L), Sabun cair, Staphylococcus aureus, Antibakteri 


\section{PENDAHULUAN}

Indonesia merupakan salah satu negara yang memiliki keanekaragaman hayati yang sangat tingggi. Dengan luas Kawasan hutan tropis terkaya kedua di dunia setelah Brazil, negara Indonesia menyimpan potensi hayati yang merupakan sumber pangan dan obat obatan yang telah lama dimanfaatkan oleh masyarakat di Indonesia. Dengan luas Kawasan yang mencapai 120,35 juta hektar Indonesia memiliki sekitar $80 \%$ dari total jenis tumbuhan yang berkhasiat obat. Salah satu tumbuhan yang berkhasiat yaitu tanaman Seledri (Apium graveolens L.) (Heriyanto,2006).

Tanaman Seledri (Apium graveolens L.) mengandung flavonoid, saponin, tannin $1 \%$, minyak atsiri $0,033 \%$, apiin, apigenin, kolin, lipase, asparagine dan vitamin (A, B dan C) (Dalimartha, 2000). Flavonoid memiliki aktivitas antiinflamasi, antioksidan, antibakteri dan sifat spasmolitik (Supriyatno dkk, 2014). Sedangkan pada Penelitian Khildah (2011), menyatakan bahwa Ekstrak Etanol Herba Seledri memiliki aktivitas antibakteri yang kuat terhadap bakteri Staphylococcus aureus pada konsentrasi 1\%, $2 \%, 4 \%$ dan $8 \%$. Sedangkan pada penelitian Kristianingsih, menyatakan bahwa Ekstrak Etanol Herba Seledri yang dijadikan sediaan gel hand sanitizer menunjukkan aktivitas antibakteri dengan konsentrasi ekstrak Seledri $12,5 \%, 15 \%$ dan $20 \%$ dengan basis CMC Na $2 \%$.

Bakteri Staphylococcus aureus dapat ditemukan pada permukaan kulit sebagai flora normal, terutama disekitar hidung, mulut, alat kelamin dan sekitar anus. Bakteri ini menyebabkan infeksi pada luka biasanya berupa abses yaitu kumpulan nanah atau cairan dalam jaringan. Jenis-jenis abses yang spesifik diantaranya bengkak, dan radang akar rambut (Dowshen, et al, 2002).

Penggunaan ekstrak tanaman Seledri sebagai antibakteri lebih mudah dalam bentuk sabun cair yang dapat digunakan sehari-hari. Sabun dibuat dengan metode saponifikasi yaitu mereaksikan trigliserida dengan soda kaustik $(\mathrm{NaOH})$ sehingga menghasilkan sabun dan produk samping berupa gliserin. Bahan baku pembuatan sabun dapat berupa lemak hewani maupun lemak/minyak nabati. Penggunaan sabun dalam kehidupan seharihari sudah tidak asing lagi, terutama sesuai dengan fungsi utamanya yaitu membersihkan. Berbagai jenis sabun ditawarkan dengan beragam bentuk mulai dari sabun cuci (krim dan bubuk), sabun mandi (padat dan cair), sabun tangan (cair) serta sabun pembersih peralatan rumah tangga (Apriana, 2013). Berdasarkan penelitian di atas peneliti tertarik untuk mengembangkan menjadi suatu sediaan Sabun cair.dan menguji efektivitasnya pada bakteri Staphylococcus aureus.

\section{METODOLOGI PENELITIAN}

Bentuk Penelitian

Penelitian ini dilakukan secara eksperimental Laboratorium (laboratory experiment). Dengan membuat formulasi sediaan sabun dan menguji aktivitas antibakteri.

\section{Waktu dan Tempat Penelitian}

Penelitian ini dilakukan di Laboratorium Farmasi lanjut dan laboratorium Mikrobiologi program studi Farmasi Universitas Sam Ratulangi Manado, pada bulan Juni 2019 - bulan September 2019.

\section{Alat dan Bahan}

Alat

Alat yang digunakan dalam penelitian ialah $\mathrm{pH}$ meter $\left(\mathrm{ATC}^{\circledR}\right)$, gelas ukur (pyrex ${ }^{\circledR}$ Iwaki), batang pengaduk, pipet tetes, erlenmeyer $\quad$ pyrex $^{\circledR}$ Iwaki), timbangan analitik (BB Adam), labu takar (pyrex $^{\circledR}$ Iwaki), cawan petri, incubator (Ecocell MMM Group), autoklaf (ALP), oven, 
blender(Philips), beker gelas (pyrex ${ }^{\circledR}$ Iwaki), penangas, piknometer (pyrex ${ }^{\circledR}$ Iwaki), jarum ose, pinset, mikropipet (Eco pipette CAPP), ayakan, mistar berskala, Hot plate, stirrer, spektrofotometer UV-Vis, aluminium foil, Cling wrap, gunting, botol sampel, plester (one med), kasa steril.

\section{Bahan}

Bahan yang digunakan dalam penelitian ini yaitu Herba Seledri, bakteri Staphylococcus aureus, minyak zaitun, kalium hidroksida $(\mathrm{KOH})$, carboksil metal celulosa (CMC), asam stearat, butyl hidroksi anisol (BHA), Sodium Lauryl sulfate(SLS), alkohol 96\%, Nutrien Agar (Oxoid), Nutrient Brooth, sabun detol, $\mathrm{NaCl} 0,9 \%, \mathrm{HCl} 0,1 \mathrm{~N}$, Fenolftalein dan Tikus Putih Galur Wistar (rattus norvegicus).

\section{Prosedur Penelitian}

\section{Pengambilan Sampel}

Sampel yang digunakan pada penelitian ini ialah Herba Seledri yang diambil di wilayah Tomohon Provinsi Sulawesi Utara. Sampel berupa Tanaman Seledri segar.

\section{Identifikasi Tanaman}

Identifikasi tanaman dilakukan di Laboratorium Biologi, Fakultas Matematika dan Ilmu Pengetahuan Alam, Universitas Sam Ratulangi, Manado.

\section{Ekstraksi}

Herba Segar sebanyak 4,5kg yang dikeringkan kemudian dihaluskan menghasilkan serbuk simplisia Herba Seledri sebanyak 480g. Dari hasil proses maserasi, remaserasi, dan penguapan didapatkan ekstrak kental 114,5g yang berwarna hijau pekat.

\section{Formulasi}


Seledri, diaduk hingga homogen. Sabun cair ditambahkan dengan aquades hingga volumenya $100 \mathrm{~mL}$, dimasukkan ke dalam wadah bersih yang telah disiapkan. Pembuatan sabun cair Ekstrak Etanol Herba Seledri disesuaikan dengan masing-masing konsentrasi. Setelah itu dilakukan Pengujian kualitas dan juga antibakteri dari masing masing konsentrasi sabun cair yang dibuat.

\section{Pengujian Kualitas Sabun Cair Uji Organoleptik}

Uji Organoleptik dilakukan untuk mengamati bentuk, warna dan bau sediaan sabun cair Ekstrak Etanol Herba Seledri.

\section{Uji pH}

$\mathrm{pH}$ diukur dengan menggunakan $\mathrm{pH}$ universal pada semua formulasi sediaan sabun cair.

\section{Uji Tinggi dan Kestabilan Busa}

Sampel sabun cair sebanyak $1 \mathrm{~g}$ dimasukkan ke dalam tabung berskala yang berisi $10 \mathrm{ml}$ aquades dan kemudian ditutup. Tabung dikocok selama 20 detik dan diukur tinggi busa yang terbentuk.

\section{Uji Kadar Air}

Penetapan kadar air dilakukan dengan metode gravimetri. Ditimbang 1 gram sampel pada cawan petri yang telah diketahui bobotnya, dipanaskan pada lemari pengering pada suhu $105^{\circ} \mathrm{C}$ selama 2 jam sampai bobot tetap.

\section{Uji Alkali Bebas}

Sampel sabun cair ditimbang sekitar $5 \mathrm{~g}$, kemudian dimasukkan ke dalam gelas piala $250 \mathrm{ml}$. Selanjutnya ditambahkan 100 $\mathrm{ml}$ alkohol $96 \%$, batu didih serta beberapa tetes larutan indikator fenolftalein. Lalu dipanaskan di atas penangas selama 30 menit sampai mendidih. Bila larutan berwarna ungu kemudian dititrasi dengan larutan $\mathrm{HCl} 0,1 \mathrm{~N}$ dalam alkohol sampai warna ungu tepat hilang.

\section{Uji Bobot Jenis}

Piknometer dikeringkan dan ditimbang. Air dimasukkan ke dalam piknometer dan didiamkan pada suhu $25^{\circ} \mathrm{C}$ selama 10 menit. Piknometer diangkat dan ditimbang. Pekerjaan diulangi dengan memakai sampel sabun cair sebagai pengganti air.

\section{Uji Iritasi}

Uji iritasi sediaan sabun cair dilakukan menggunakan hewan uji Tikus Putih dengan metode Draize test (1959). Penelitian ini menggunakan 18 ekor Tikus Putih. Rambut pada bagian punggung Tikus dicukur sampai bersih. Punggung Tikus lalu dibuat menjadi 1 bagian yang berbentuk bujur sangkar, yang akan diberikan perlakuan sediaan sabun dengan konsentrasi $1 \%, 2 \%, 4 \%$, dan $8 \%$, Masing-masing sampel sabun sebanyak 0,5 g dioleskan pada bagian punggung Tikus yang telah dicukur, lalu ditutup dengan kasa steril kemudian direkatkan dengan plester. Setelah 24 jam, plester dan perban dibuka dan dibiarkan selama 1 jam, lalu diamati. Setelah diamati, bagian tersebut ditutup kembali dengan plester yang sama dan dilakukan pengamatan kembali setelah 72 jam (Irsan dkk, 2013).

\section{Uji antibakteri}

Pengujian antibakteri dilakukan dengan metode dilusi cair Kirby and Bauer yang dimodifikasi (Lennete, dkk.,1991) menggunakan media cair Nutrien Broth (NB) dan diukur absorbansi dengan spektrofotometer UV-Vis sebelum dan sesudah inkubasi untuk melihat pertumbuhan bakteri uji. 


\section{HASIL DAN PEMBAHASAN}

Pengamatan organoleptik dilakukan dengan melihat bentuk, bau dan warna dari sediaan Sabun Cair. Hasil pengamatan organoleptik dapat dilihat pada Tabel 2.

Tabel 2. Hasil Uji Organoleptik

\begin{tabular}{cccc}
\hline $\begin{array}{c}\text { Formulasi } \\
\text { Sediaan sabun } \\
\text { cair }\end{array}$ & Bentuk & Warna & Bau \\
\hline F0 (Tanpa & Cair, & Kuning & Bau Minyak \\
Ekstrak) & Kental & & zaitun \\
F1 (1\%) & Cair, & Hijau & Bau Khas \\
& Kental & Muda & Seledri \\
F2 (2\%) & Cair, & Hijau & Bau Khas \\
& Kental & pekat & Seledri \\
F3 (4\%) & Cair, & Hijau & Bau Khas \\
& Kental & pekat & Seledri \\
F4 $(8 \%)$ & Cair, & Hijau & Bau Khas \\
& Kental & pekat & Seledri \\
\hline
\end{tabular}

Uji organoleptik dimaksudkan untuk melihat penampakan atau tampilan fisik suatu sediaan yang meliputi bentuk, warna dan bau. Standar yang ditetapkan SNI, standar untuk uji organoleptik sabun cair, bentuk yaitu cair, bau dan warna yaitu memiliki bau dan warna yang khas. Pengujian organoleptik sediaan sabun cair ekstrak etanol herba Seledri untuk hasilnya menunjukan bahwa sabun dengan konsentrasi $1 \%, 2 \%$, 4\%,dan $8 \%$ memiliki bentuk Cair sedangkan bau menyerupai bau khas Seledri serta warna yang mengikuti warna ekstrak Seledri yaitu hijau pekat kecuali konsentrasi $1 \%$ yang memiliki warna hijau muda karena disebabkan oleh penambahan konsentrasi yang sedikit sehingga menyebabkan warna hijau pekat yang bercampur dengan basis berubah menjadi hijau muda. Sedangkan untuk basis sendiri berwarna kuning. Berdasarkan hasil yang diperoleh, hasil pada penelitian ini sesuai dengan standar yang ditetapkan SNI.

Tabel 3. Hasil Uji PH

\begin{tabular}{|c|c|c|}
\hline $\begin{array}{c}\text { Formulasi Sediaan sabun } \\
\text { cair }\end{array}$ & PH & Keterangan \\
\hline F0 (Tanpa Ekstrak) & 10,2 & $\begin{array}{c}\text { Memenuhi } \\
\text { Syarat }\end{array}$ \\
\hline $\mathrm{F} 1(1 \%)$ & 9,8 & $\begin{array}{c}\text { Memenuhi } \\
\text { Syarat }\end{array}$ \\
\hline $\mathrm{F} 2(2 \%)$ & 9,8 & $\begin{array}{l}\text { Memenuhi } \\
\text { Syarat }\end{array}$ \\
\hline F3 (4\%) & 9,6 & $\begin{array}{c}\text { Memenuhi } \\
\text { Syarat }\end{array}$ \\
\hline F4 (8\%) & 9,5 & $\begin{array}{l}\text { Memenuhi } \\
\text { Syarat }\end{array}$ \\
\hline
\end{tabular}

Uji $\mathrm{pH}$ merupakan salah satu syarat mutu sabun cair. Hal tersebut karena sabun cair kontak langsung dengan kulit dan dapat menimbulkan masalah apabila pH-nya tidak sesuai dengan $\mathrm{pH}$ kulit. Kulit memiliki kapasitas ketahanan dan dapat dengan cepat beradaptasi terhadap produk yang memiliki pH 8.0-10.8 (Frost et al., 1982). Hasil pengujian $\mathrm{pH}$ yang telah dilakukan menunjukan nilai $\mathrm{pH}$ 9,5 untuk konsentrasi $8 \%, 9,6$ untuk konsentrasi 4\%, 9,8 untuk konsentrasi 2\%, 9,8 untuk konsentrasi $1 \%$ dan 10,2 untuk basis, Nilai $\mathrm{pH}$ ini di pengaruhi oleh bahan penyusun sabun yaitu $\mathrm{KOH}$ yang merupakan basa kuat. Menurut SNI, untuk pH sabun cair diperbolehkan antara 8-11. Hasil menunjukan semua formula sabun cair yang dihasilkan memenuhi kriteria sabun cair yang baik.pH yang tinggi dapat menyebabkan kulit iritasi karena memiliki tingkat akali bebas yang tinggi. Tingkat alkali bebas dalam sabun ini disebabkan oleh adanya alkali yang tidak bereaksi dengan asam lemak dalam proses saponifikasi (Zulkifli dan Estiasih, 2014). Besarnya jumlah alkali dalam tiap formula adalah sama, sehingga $\mathrm{pH}$ antar formula tidak memiliki perbedaan yang cukup signifikan. 
Uji tinggi busa dilakukan untuk melihat daya busa yang dihasilkan sabun cair yang dibuat sesuai dengan standar tinggi busa sabun yang ditetapkan oleh Standar Nasional Indonesia (SNI) yaitu 13-220 mm. Hasil uji tinggi busa dapat dilihat pada Tabel 4.

Tabel 4. Hasil Uji Tinggi dan Kestabilan Busa

\begin{tabular}{cc}
\hline $\begin{array}{c}\text { Formulasi Sediaan } \\
\text { sabun cair }\end{array}$ & Tiinggi Busa (mm) \\
\hline Basis & 30 \\
$1 \%$ & 30 \\
$2 \%$ & 30 \\
$4 \%$ & 35 \\
$8 \%$ & 40 \\
\hline
\end{tabular}

Untuk uji tinggi dan kestabilan busa Berdasarkan SNI, syarat tinggi buih/busa dari sabun cair yaitu 13-220 mm. Pengujian tinggi busa menggunakan tabung berskala, dari hasil pengamatan tinggi busa didapat dari basis sabun cair $30 \mathrm{~mm}$, sedangkan untuk formulasi sabun cair $1 \% 30 \mathrm{~mm}, 2 \% 30 \mathrm{~mm}, 4 \% 35$ $\mathrm{mm}$, dan $8 \% 40 \mathrm{~mm}$. makin besar konsentrasi maka makin banyak busa yang dihasilkan, busa yang dihasilkan berasal dari senyawa saponin yang dimiliki oleh herba Seledri. Busa pada sabun berfungsi untuk mengangkat minyak atau lemak pada kulit, jika busa yang dimiliki oleh sabun terlalu tinggi maka dapat membuat kulit kering, saat lemak di kulit hilang, maka akan membuat kulit lebih rentan terhadap iritasi, karena Lemak pada kulit ini bermanfaat sebagai pertahanan, Lapisan paling atas kulit disebut sawar kulit, salah satu penyusun sawar kulit adalah lemak. Lemak akan membuat sawar kulit lebih rapat, agar bakteri maupun mikroorganisme tidak mudah untuk masuk dalam tubuh.

Uji kadar air dilakukan untuk mengetahui presentase kandungan air dalm sabun cair. Menurut SNI, kadar air dalam sediaan sabun cair maksimal $60 \%$. Hasil uji kadar air dapat dilihat pada tabel 5.
Tabel 5. Hasil Uji Kadar Air

\begin{tabular}{ccccc}
\hline $\begin{array}{c}\text { Konsentrasi } \\
(\%)\end{array}$ & $\begin{array}{c}\text { Berat } \\
\text { Cawan } \\
\text { (Gram) }\end{array}$ & $\begin{array}{c}\text { Berat } \\
\text { Awal } \\
\text { Sampel } \\
\text { (Gram) }\end{array}$ & $\begin{array}{c}\text { Berat } \\
\text { Akhir } \\
(\text { Gram) }\end{array}$ & $\begin{array}{c}\text { Kadar } \\
\text { Air } \\
(\%)\end{array}$ \\
\hline $1 \%$ & 43,963 & 1,068 & 44,485 & 51,12 \\
$2 \%$ & 49,851 & 1,008 & 50,357 & 49,80 \\
$4 \%$ & 43,172 & 1,023 & 43,711 & 47.31 \\
& & & & \\
$8 \%$ & 37,870 & 1,004 & 38,555 & 31,77 \\
& & & & \\
\hline
\end{tabular}

Uji kadar air dilakukan untuk mengetahui presentase kandungan air yang terdapat pada masing-masing sediaan. Standar kadar air yang ditetapkan oleh SNI yaitu maksimal $60 \%$. Untuk pengujian kadar air dilakukan dengan cara menimbang terlebih dahulu cawan petri lalu menimbang berat sampel lalu dimasukan kedalam oven bersuhu $105^{\circ} \mathrm{C}$ selama 2 jam, setelah 2 jam sampel beserta sawan petri yang telah dipanaskan ditimbang lalu dihitung menggunakan rumus kadar air sehingga diperoleh hasil yang berkisar dari 31,77-52,24 (Lampiran 4). Kadar air sabun cair sangat dipengaruhi oleh kecepatan mixing dan konsentrasi. Berdasarkan hasil yang diperoleh kadar air yang dihasilkan, semakin besar konsentrasi ekstrak yang ditambahkan maka semakin kecil presentase kadar air yang didapatkan. Kadar air yang tinggi juga dapat dipengaruhi oleh bahan--bahan yang bersifat higroskopis yaitu seperti SLS, CMC dan juga dapat dipengaruhi oleh penambahan aquadest.

Uji alkali bebas dilakukan untuk mengetahui ada tidaknya alkali bebas pada sabun cair. Menurut SNI, alkali bebas dalam suatu sediaan sabun cair maksimal $0,1 \%$. Hasil uji alkali bebas dapat dilihat pada Tabel 6.

Tabel 6. Hasil Uji Alkali Bebas

$\begin{array}{lll}\text { Konsentrasi } & \text { V } & \text { Kadar Alkali }\end{array}$




\begin{tabular}{ccc}
\hline $\mathbf{( \% )}$ & & Bebas (\%) \\
\hline 1 & 0,80 & 0,089 \\
2 & 0,82 & 0,091 \\
4 & 0,85 & 0,095 \\
8 & 0,88 & 0,098 \\
\hline
\end{tabular}

Kadar alkali bebas yang didapatkan dari masing-masing konsentrasi sabun cair yaitu 0,089\%-0,098 Lampiran 5. Berdasarkan SNI, standar alkali bebas pada sabun cair yaitu maksimal $0,1 \%$. Hal ini menunjukan bahwa sabun cair Ekstrak Etanol Herba Seledri terbukti sesuai dengan standar yang ditetapkan oleh SNI. Kurangnya kandungan alkali bebas yang terdapat dalam sabun cair, ini disebabkan karena pada pembuatan basis sabun cair dilakukan pemanasan yang lama hingga sabun menjadi pasta yang kering sehingga kalium hidroksida yang merupakan salah satu pembentukan basis sabun sudah bereaksi dengan lemak atau minyak zaitun.

Uji bobot jenis dilakukan untuk mengetahui bobot jenis dari sabun cair. Bobot jenis dari suatu sediaan sabun cair menurut SNI adalah 1,01 - 1,1 g/mL. hasil uji bobot jenis dapat dilihat pada Tabel 7.

Tabel 7. Hasil Uji Bobot Jenis

\begin{tabular}{cc}
\hline Konentrasi (\%) & Bobot Jenis $(\mathbf{g} / \mathbf{m l})$ \\
\hline 1 & 1,042 \\
2 & 1,036 \\
4 & 1,034 \\
8 & 1,012 \\
\hline
\end{tabular}

Pengujian bobot jenis dilakukan untuk mengetahui pengaruh bahan-bahan yang digunakan dalam formulasi sabun cair yaitu bahan yang terdapat dalam formula terhadap bobot jenis sabun yang dihasilkan. Berdasarkan SNI, standar bobot jenis pada sabun cair yaitu 1,01 - 1,1 g/mL. Pengujian bobot jenis menggunakan Piknometer, dari hasil pengamatan diperoleh bobot jenis dari basis sabun $1,108 \mathrm{~g} / \mathrm{mL}$, bobot jenis konsentrasi $1 \% \quad 1,042 \mathrm{~g} / \mathrm{mL}$, bobot jenis konsentrasi $2 \% \quad 1,036 \mathrm{~g} / \mathrm{mL}$, bobot jenis konsentrasi $4 \% \quad 1,034 \mathrm{~g} / \mathrm{mL}$, bobot jenis Konsentrasi $8 \%$ 1,012. bobot jenis dari masing-masing konsentrasi memiliki perbedaan yang jelas, semua konsentrasi memiliki bobot jenis sabun cair yang sesuai dengan standar yang ditetapkan oleh SNI. Nilai bobot jenis dipengaruhi suatu bahan penyusunnya dan sifat fisiknya. Menurut Gaman dan sherington (1990) penurunan bobot jenis disebabkan oleh adanya lemak atau etanol dalam larutan.

Uji iritasi dilakukan untuk melihat apakah sabun yang dibuat dapat mengiritasi kulit atau aman untuk digunakan, berdasarkan indeks iritasi pada table 2, maka dapat disimpulkan bahwa hasil uji iritasi pada sabun cair dengan konsentrasi 1\%, 2\%, 4\% dan $8 \%$ tidak mengiritasi kulit dan aman untuk digunakan.

Tabel 8. Hasil Uji Iritasi

\begin{tabular}{cccc}
\hline Konsentrasi & 24 Jam & 72 Jam & Hasil \\
\hline K+ & 0 & 0 & 0 \\
K- & 0,3 & 0,3 & 0,3 \\
$\mathbf{1 \%}$ & 0 & 0 & 0 \\
$\mathbf{2 \%}$ & 0 & 0 & 0 \\
$\mathbf{4 \%}$ & 0 & 0 & 0 \\
$\mathbf{8 \%}$ & 0 & 0 & 0 \\
\hline
\end{tabular}

Pengujian iritasi menggunakan 18 ekor tikus putih yang dicukur bulunya hingga bersih lalu dioleskan sabun cair dipunggung tikus lalu ditutup menggunakan kasa dan di plester lalu diamati setelah 24 jam, diamati kembali pada hari yang ke-3 (72 jam) setelah pengamatan dan hasilnya dicatat kemudian dilakukan perhitungan sehingga memperoleh hasil tidak ditemukan iritasi pada konsentrasi $1 \%, 2 \%, 4 \%$, dan $8 \%$, dan untuk basis sabun 
ditemukan iritasi ringan, hal ini dapat dipengaruhi oleh $\mathrm{pH}$ yang tinggi sehingga kandungan alkali yang dimiliki dapat menyebabkan iritasi.

Hasil uji antibakteri yang dibaca pada spektrofotometer UV-Vis setelah dijumlahkan menunjukan adanya aktivitas daya hambat pada bakteri dan adanya daya bunuh bakteri pada konsentrasi $4 \%$ dan $8 \%$ hal ini ditunjukan dengan berkurangnya absorbansi setelah diinkubasi, besarnya absorbansi menunjukan berkurangnya jumlah bakteri. Hasil uji antibakteri dapat dilihat pada tabel 9.

Tabel 9. Hasil Uji Antibakteri

\begin{tabular}{cccc}
\hline Formula & $\begin{array}{c}\text { Sebelum } \\
\text { Inkubasi } \\
(\mathbf{n m})\end{array}$ & $\begin{array}{c}\text { Sesudah } \\
\text { Inkubasi } \\
(\mathbf{n m})\end{array}$ & $\begin{array}{c}\text { Rata-rata } \\
\text { Absorbansi } \\
(\mathbf{n m})\end{array}$ \\
\hline $\mathbf{K +}$ & 0,15 & 0,399 & 0,249 \\
$\mathbf{K}-$ & 1,346 & 2568 & 1,222 \\
$\mathbf{1 \%}$ & 1,009 & 2,276 & 1,267 \\
$\mathbf{2 \%}$ & 1,352 & 1,802 & 0,45 \\
$\mathbf{4 \%}$ & 2,379 & 2,342 & $-0,037$ \\
$\mathbf{8 \%}$ & 2,970 & 2,846 & $-0,124$ \\
\hline
\end{tabular}

Untuk pengujian antibakteri dilakukan dengan cara dilusi, hasil yang diperoleh ialah 0,249 sebagai kontrol positif, 1,222 sebagai kontrol negatif, 1,267 untuk konsentrasi $1 \%$, 0,45 untuk konsentrasi 2\%, -0,037 untuk konsentrasi $4 \%$ dan -0,124 untuk konsentrasi $8 \%$. Konsetrasi $1 \%$ dianggap memiliki daya hambat yang kecil atau tidak memiliki daya hambat karena dilihat dari nilai absorbansi yang di peroleh konsentrasi $1 \%$ memiliki nilai yang setara bahkan lebih besar sedikit daripada nilai absorbansi kontrol negatif, sedangkan pada konsentrasi $2 \%, 4 \%$, dan $8 \%$, memiliki aktivitas antibakteri yang tinggi karena nilai absorbansi yang diperoleh lebih kecil dibandingkan kontrol positif untuk hasil lebih jelas dapat dilihat pada lampiran 7 . Semakin kecil nilai absorbansi maka semakin besar daya hambat bakteri nilai minus pada rata-rata absorbansi menunjukan bahwa bakteri yang di campur Bersama sampel dalam media mengalami pengurangan jumlah khususnya pada konsentrasi $4 \%$ dan $8 \%$ hal ini menunjukan bahwa sampel pada konsentrasi tersebut tidak hanya memiliki daya hambat yang kuat tetapi juga memiliki daya bunuh terhadap bakteri.

Pada penelitian khilda yang menggunakan herba Seledri pada pengujian antibakteri terhadap staphylococcus aureus didapatkan diameter zona hambat pada konsentrasi $1 \%$ sebesar $20,3 \mathrm{~mm}, 2 \%$ sebesar $21,3 \mathrm{~mm}, 4 \%$ sebesar $22,2 \mathrm{~mm}$ hal ini menunjukan bahwa semakin besar konsentrasi sampel semakin besar pula daya hambat yang dihasilkan sedangkan pada penelitian kristianingsih yang membuat gel hand sanitizer menggunakan daun Seledri diperoleh diameter zona hambat tertinggi pada konsentrasi $20 \%$ dengan daya hambat $14 \mathrm{~mm}$ sedangkan pada konsentrasi $15 \%$ memilii zona hambat $13 \mathrm{~mm}$ dan $12,5 \%$ memiliki zona hambat $12 \mathrm{~mm}$ hal ini menunjuan bahwa daun Seledri juga memiliki daya hambat bakteri tetapi tidak sebesar herba Seledri .

\section{KESIMPULAN}

Berdasarkan dari hasil penelitian yang telah dilakukan maka, dapat disimpulkan bahwa:

1. Ekstrak etanol Herba Seledri dapat diformulasi dalam bentuk sediaan Sabun cair antibakteri.

2. Sabun cair herba Seledri pada konsentrai $1 \%, 2 \%, 4 \%$, dan $8 \%$ memiliki aktivitas antibakteri, khususnya pada konsentrasi 8\% Memiliki daya hambat dan daya bunuh yang kuat.

\section{SARAN}

Perlu dilakukan penelitian lebih lanjut untuk sediaan sabun cair terlebih khusus pada pengujian antibakteri menggunakan metode difusi (sumuran) agar dapat mengetahui besar daya hambat sabun cair Ekstrak Etanol Herba 
Seledri terhadap bakteri staphylococcuss aureus.

\section{DAFTAR PUSTAKA}

Badan Standarisasi Nasional. 1996. Standar Sabun Mandi Cair. SNI 06-40851996, Dewan Standarisasi Nasional, Jakarta.

Draize, J.H. 1959. Dermal Toxicity. The Association of Food and Drug Officials of the United States : Bureau of Food and Drugs.

Irsan, M.A, Manggav, E., Pakki., Usmar,. 2013. Uji Iritasi Krim Antioksidan Ekstrak Biji Lengkeng (Euphoria longana Stend) pada Kulit Kelinci (Oryctolagus cuniculus). Majalah Farmasi dan Farmakologi. 17(2):5560

Khilda, K., Ihwan. Uji Efek Antibakteri Ekstrak Etanol Herba Seledri (Apium graveolens Linn.) Terhadap Escherichia coli dan Staphylococcus aureus dan Analisis KLT Bioautografi, Jurnal Biocelebes, Universitas Tadulako, Palu. 5:13-21.

Zulkifli, M., dan Estiasih, T., 2014, Sabun dari Distilat Asam Lemak Minyak Sawit, Jurnal Pangan dan Agroindustri. 2(4), 170-177. 